\title{
Determination of $\mathrm{As}, \mathrm{Cd}$, and $\mathrm{Pb}$ in Tap Water and Bottled Water Samples by Using Optimized GFAAS System with Pd-Mg and Ni as Matrix Modifiers
}

\author{
Sezgin Bakırdere, ${ }^{1}$ Tolga Yaroğlu, ${ }^{2}$ Nihan Tırık, ${ }^{3}$ Mehmet Demiröz, ${ }^{4}$ A. Kemal Fidan, ${ }^{5}$ \\ Onur Maruldal, ${ }^{6}$ and Abdullah Karaca ${ }^{7}$ \\ ${ }^{1}$ Department of Sciences Education, Yıldiz Technical University, İstanbul, Turkey \\ ${ }^{2}$ Faculty of Veterinary Medicine, Ankara University, Ankara, Turkey \\ ${ }^{3}$ Department of Biology, Samsun 19 Mayss University, Samsun, Turkey \\ ${ }^{4}$ Karacabey MYO, Uludag University, Karacabey-Bursa, Turkey \\ ${ }^{5}$ Department of Chemistry, Süleyman Demirel University, Isparta, Turkey \\ ${ }^{6}$ Department of Biology, Çukurova University, Adana, Turkey \\ ${ }^{7}$ Faculty of Veterinary Medicine, Firat University, Elazig, Turkey \\ Correspondence should be addressed to Sezgin Bakırdere; bsezgin23@yahoo.com
}

Received 6 June 2012; Accepted 30 July 2012

Academic Editor: Massimo Tallarida

Copyright ( 2013 Sezgin Bakurdere et al. This is an open access article distributed under the Creative Commons Attribution License, which permits unrestricted use, distribution, and reproduction in any medium, provided the original work is properly cited.

\begin{abstract}
Arsenic, lead and cadmium were determined in tap and bottled water samples consumed in the west part of Turkey at trace levels. Graphite Furnace Atomic Absorption Spectrometry (GFAAS) was used in all detections. All of the system parameters for each element were optimized to increase sensitivity. Pd-Mg mixture was selected as the best matrix modifier for As while the highest signals were obtained for $\mathrm{Pb}$ and $\mathrm{Cd}$ in the case of $\mathrm{Ni}$ used as matrix modifier. Detection limits for $\mathrm{As}, \mathrm{Cd}$, and $\mathrm{Pb}$ were found to be 2.0, 0.036 and $0.25 \mathrm{ng} / \mathrm{mL}$, respectively. 78 tap water and 17 different brands of bottled water samples were analyzed for their As, $\mathrm{Cd}$ and $\mathrm{Pb}$ contents under the optimized conditions. In all water samples, concentration of cadmium was found to be lower than detection limits. Lead concentration in the samples analyzed varied between N.D. and $12.66 \pm 0.68 \mathrm{ng} / \mathrm{mL}$. The highest concentration of arsenic was determined as $11.54 \pm 2.79 \mathrm{ng} / \mathrm{mL}$. Accuracy of the methods was verified by using a certified reference material namely Trace Element in Water, 1643e. Results found for $\mathrm{As}, \mathrm{Cd}$, and $\mathrm{Pb}$ in reference materials were in satisfactory agreement with the certified values.
\end{abstract}

\section{Introduction}

Our green planet has been contaminated from day to day by different contaminants. One of the most serious contaminant groups is the heavy metals. Our ecosystem has been contaminated by high concentration of heavy metals released into the biosphere by human activity. Industrial activities, energy production, construction, urban waste treatment, and vehicle exhaust are some of the sources causing large quantities of heavy metal contamination in atmosphere, water, and soil [1].

Arsenic has been listed as one of the human carcinogens by the International Agency for Research on Cancer (IARC) since 1980. There have been many studies in the literature to show the positive association between arsenic exposure and cancer in different countries including the USA, Taiwan, Bangladesh, and India [2]. Blander cancer [3], skin cancer [4], and lung cancer [5] are some of the cancer types associated to arsenic exposure by many researchers. In addition to carcinogenic effects, there are some noncarcinogenic effects of chronic arsenic exposure [2]. According to Tsai et al., longterm accumulated arsenic in adolescence may cause neurobehavioral effects and exposure to high amount of arsenic may affect behavior later in life. In addition, in the case of lead, effects will be more severe by synergistic behavior of arsenic and lead [6]. There are many sources of arsenic exposure. One 
of the big sources for human to inorganic arsenic exposure is groundwater. High concentration of arsenic in groundwater has been recognized as global concern [2].

Toxic effects of cadmium and lead are also well known [7]. Cadmium is not regarded as essential element for human being and known to be an element damaging organs such as the kidneys, liver, and lungs [8]. It is known that cadmium accumulates in both liver and kidneys and half-life of this element in human body is between one and four decades [9]. Exposure to high amount of cadmium can cause damages in central nervous and immune systems in addition to fertility disorders and occurrence of different cancer types $[9,10]$. Toxic effect of lead is also studied. One of the molecular mechanisms for toxicity of lead is oxidative stress [11]. By the effect of lead, reactive oxygen species (ROS) levels increase via elevated intracellular $\mathrm{Ca}^{2+}[12]$. There are different types of lead sources causing food, water contamination, and air pollution by industrial emission. According to Ahamed and Siddiqui, diet, lead-based paint in older housing, lead in soil and dust from contaminated leaded paint and gasoline, and mining and other industrial activities are the main sources of lead for children. By the displacement of leaded gasoline with unleaded one and lead water pipes and water tanks with nonlead alternatives, lead exposure from these sources has been reduced on a large scale [13]. It was also stated that anthropogenic contribution to cadmium and lead contamination is more important than natural input [14].

Due to the adverse health effects of arsenic, lead, and cadmium, detection of trace amount of these elements in any environmental samples related with human being is very important. Determination of these elements requires sufficiently sensitive techniques for detection at the $\mu \mathrm{g} / \mathrm{L}$ or sublevels. In the literature, there are many techniques including atomic absorption spectrometry (AAS) $[15,16]$, graphite furnace atomic absorption spectrometry (GFAAS) [17, 18], inductively coupled plasma optical emission spectrometry (ICP-OES) $[19,20]$, and inductively coupled plasma mass spectrometry (ICP-MS) [21, 22] for the determination of As, $\mathrm{Pb}$, and $\mathrm{Cd}$ in different matrices. Although AAS has been used for many elements in variety of matrices [23, 24], there is sensitivity problem for many elements in the case of using this instrument. Due to the high sensitivity, low cost, and easy operation, GFAAS has been popularly used in literature for $\mathrm{As}, \mathrm{Pb}$ and $\mathrm{Cd}[25]$.

The main purpose of this study was to analyze tap water and bottled water samples for their $\mathrm{As}, \mathrm{Cd}$, and $\mathrm{Pb}$ contents by using optimized GFAAS system with Pd-Mg and $\mathrm{Ni}$ as matrix modifiers.

\section{Experimental}

2.1. Apparatus and Reagents. In order to determine As, $\mathrm{Cd}$, and $\mathrm{Pb}$ in water samples, GFAAS instrument equipped with hollow cathode lamps (HCLS) was used. Instrumental parameters used throughout this study for the elements of interest can be seen in Table 1. Deuterium arc lamp background correction was applied for all the analytes.
TABLE 1: GF-AAS parameters used in the determination of As, Cd, and $\mathrm{Pb}$.

\begin{tabular}{lccc}
\hline & As & $\mathrm{Cd}$ & $\mathrm{Pb}$ \\
\hline Lamp current, mA & 10 & 4.0 & 5.0 \\
Slit width, nm & 0.5 & 0.5 & 0.5 \\
Wavelength, nm & 193.7 & 228.8 & 283.3 \\
Background correction & $\mathrm{D}_{2}$ & $\mathrm{D}_{2}$ & $\mathrm{D}_{2}$ \\
\hline
\end{tabular}

All of the chemicals used throughout the experiments were in high-purity grade. In all dilutions and standard preparation, double distilled water was used. All of the containers were washed up with hot nitric acid and then rinsed with double distilled water before using in the experiments. All glass beakers and containers were kept and stored in $1.0 \mathrm{~mol} / \mathrm{L} \mathrm{HNO}_{3}$ to eliminate any possible contamination. Nitric acid (65\%, Merck) was used to eliminate the precipitation of analytes before measurement. In the preparation of working standards of analytes, proper dilutions were done by $1.0 \mathrm{~mol} / \mathrm{L}$ nitric acid from the stock solutions of As, Cd, and $\mathrm{Pb}(1000 \mathrm{mg} / \mathrm{L}) .20 \mu \mathrm{L}$ of samples and calibration solutions were pipetted into the graphite tube in the measurements. High purity $\mathrm{N}_{2}$ was used as sheath gas. $500 \mathrm{mg} / \mathrm{L}$ of palladium and magnesium mixture for arsenic and $1010 \mathrm{mg} / \mathrm{L}$ of nickel for cadmium and lead were used as stock solutions of matrix modifiers. Standard reference material (Trace Element in Water, 1643e) bought from NIST was used for evaluating methods used in the determination of $\mathrm{As}, \mathrm{Cd}$, and $\mathrm{Pb}$ in water samples.

2.2. Sample Collection. Tap water samples were collected in three cities, namely, Kocaeli, Adapazarı, Düzce located in the west part of Turkey. 78 different sampling points were selected in these cities for homogenous representation of the region. Map of these cities is shown in Figure 1.

In the sample collection, bottles used for the samples were previously rinsed with double distilled water. One litter of tap water samples was collected for arsenic, cadmium, and lead determinations. Samples were brought to the laboratory and kept in the fridge prior to analysis. In addition, 17 different brands of bottled water samples were bought from the local markets of these cities. In the selection of these brands, consumption rates were considered. All the samples were analyzed within two days after sample collection to eliminate or minimize not only precipitation of analytes but also any possible contaminations.

\section{Result and Discussion}

All of the system parameters were optimized for each analyte to increase sensitivity. While optimizing, all the parameters were kept constant except one variable at a time.

\subsection{Optimization of Temperature Program of GFAAS System} for Analytes. Determination of arsenic in environmental matrices by using GFAAS has some difficulties. Many arsenic species are highly volatile, and possibility of losses of arsenic 
TABLE 2: Temperature program used in the determination of As.

\begin{tabular}{lccccccccc}
\hline & \multicolumn{3}{c}{ Temperature, ${ }^{\circ} \mathrm{C}$} & \multicolumn{3}{c}{ Ramp, s $\left(\mathrm{N}_{2}, \mathrm{~L} / \mathrm{min}\right)$} & \multicolumn{3}{c}{ Hold, s $\left(\mathrm{N}_{2}, \mathrm{~L} / \mathrm{min}\right)$} \\
& $\mathrm{As}$ & $\mathrm{Cd}$ & $\mathrm{Pb}$ & $\mathrm{As}$ & $\mathrm{Cd}$ & $\mathrm{Pb}$ & $\mathrm{As}$ & $\mathrm{Cd}$ & $10(0.2)$ \\
\hline Drying & 140 & 130 & 120 & $15(0.2)$ & $25(0.2)$ & $20(0.2)$ & $15(0.2)$ & $10(0.2)$ & $10.0(0.2), 1.0(0)$ \\
Ashing & 600 & 280 & 380 & $10(0.2)$ & $10(0.2)$ & $10(0.2)$ & $10(0.2), 1.5(0)$ & $5.0(0.2)$ \\
Atomization & 2300 & 1800 & 2000 & $0.9(0)$ & $0.8(0)$ & $0.9(0)$ & $1.0(0)$ & - & - \\
Cleaning & 2600 & 2500 & 2500 & $1.0(1.0)$ & $2.0(1.0)$ & $2.0(1.0)$ & $3.0(1.0)$ & - & - \\
\hline
\end{tabular}

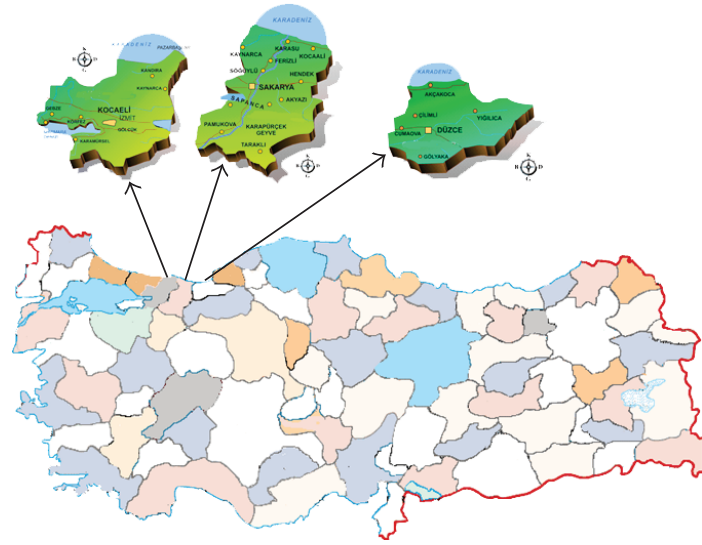

FIGURE 1: Map of sampling points (http://www.csb.gov.tr/, 21.12.2012).

during the ashing step is very high. Spectral interferences which appear in the presence of some anion and cations such as phosphate, iron, and aluminum are associated with the atomization step [26]. Hence, the optimization of temperature program of arsenic is very crucial to eliminate or minimize both analyte losses and possible interferences. Loss of arsenic was observed at the ashing temperature of $600^{\circ} \mathrm{C}$. The highest signal was obtained when the temperature at the atomization step set to $2300^{\circ} \mathrm{C}$. Optimum drying, ashing, and atomization temperatures were found to be 140, 600, and $2300^{\circ} \mathrm{C}$, respectively. Cleaning of graphite tube was performed at a temperature of $2600^{\circ} \mathrm{C}$. Optimum flow rate of sheath gas was found to be $0.2 \mathrm{~L} / \mathrm{min}$ in drying and ashing steps, while this value was set to $1.0 \mathrm{~L} / \mathrm{min}$ in the cleaning step.

It is known that $\mathrm{Cd}$ is one of the high volatile elements and it has less vaporization heat and low appearance temperature in the case of GFAAS measurements [27]. In this study, sensitivity of cadmium began to be lost at the ashing temperature which is higher than $280^{\circ} \mathrm{C}$. The highest absorption was obtained at the atomization temperature of $1800^{\circ} \mathrm{C}$. Optimum flow rates of $\mathrm{N}_{2}$ were $0.2 \mathrm{~L} / \mathrm{min}$ in drying and ashing steps, and $1.0 \mathrm{~L} / \mathrm{min}$ in the cleaning step.

Lead is also known as a comparatively volatile element [27]. Temperature program for the analysis of lead is also optimized to provide maximum matrix decomposition without loss of lead in any step of GFAAS program. Absorption of lead started to decrease at the ashing temperature of $350^{\circ} \mathrm{C}$. The highest lead signal was obtained at the atomization temperature of as high as $1800^{\circ} \mathrm{C}$. The same flow rates of
$\mathrm{N}_{2}$ with As and Cd were applied in the drying, ashing, and cleaning steps. Cleaning step was performed at a temperature of $1800^{\circ} \mathrm{C}$ in 2 seconds. Temperature programs for As, Cd, and $\mathrm{Pb}$ can be seen in Table 2 .

3.2. Optimization of Type and Amount of Matrix Modifier. It is well known that matrix modifiers are used to both stabilize the analytes during the graphite furnace cycle and permit increases in the charring and atomization temperatures. Better separation of the element from interferences can be achieved by using proper matrix modifiers [28].

In order to stabilize arsenic at higher temperature of the ashing stage, different types of matrix modifiers, namely, palladium, magnesium, and mixture of palladium-magnesium were tried. In the optimization, $40 \mathrm{ng} / \mathrm{mL}$ of arsenic standard and 1.0 microgram of each modifier were used. Sensitivity was enhanced 2.23 times by using palladium-magnesium mixture, while this value was 1.91 in the presence of palladium. The highest signal was obtained in the case of palladium-magnesium mixture as matrix modifier, and arsenic signal was better in terms of sharpness and peak shape. Most probably palladium-magnesium mixture equalizes the thermal behavior of arsenic species in the water samples. The effect of the different masses of palladiummagnesium mixture as matrix modifier on arsenic signal was also investigated. $0.5,1.0,2.0$, and $3.0 \mu \mathrm{g}$ of palladiummagnesium were tried in this optimization. It was observed that arsenic signal was getting lower with higher amount of matrix modifier. Hence, $0.5 \mu \mathrm{g}$ of each of palladium and magnesium as a mixture of modifier was selected as optimum modifier amount for the further real sample measurements.

Similar optimization studies were also performed for cadmium. Nickel, palladium, and palladium-magnesium mixture were tried to find relatively the best matrix modifier. In the optimization of matrix modifier type, $2.0 \mathrm{ng} / \mathrm{mL}$ of cadmium standard and 0.2 microgram of each modifier were used. There was no difference observed between the cadmium signals obtained from $2.0 \mathrm{ng} / \mathrm{mL}$ Cd solution with and without Pd-Mg mixture as matrix modifier. In the case of Pd, cadmium signal decreased about $3 \%$ while signal was enhanced 1.27 times by using nickel as a matrix modifier. Hence, nickel was selected as an effective matrix modifier for the determination of cadmium for real sample measurements. $0.25,0.5,1.0,2.0$, and $4.0 \mu \mathrm{g}$ of nickel were tried in the optimization of the amount of matrix modifier.

It is clear in Figure 2 that cadmium signal decreased by using the nickel which is more or less than $1.0 \mu \mathrm{g}$. Therefore, $1.0 \mu \mathrm{g}$ of nickel was found to be the best matrix modifier and 
TABle 3: Analytical figures of merit for $\mathrm{As}, \mathrm{Cd}$, and $\mathrm{Pb}$.

\begin{tabular}{lccc}
\hline & Arsenic & Cadmium & Lead \\
\hline Limit of detection (LOD), $\mathrm{ng} / \mathrm{mL}$ & 2.0 & 0.036 & 0.25 \\
Limit of quantitation (LOQ), $\mathrm{ng} / \mathrm{mL}$ & 6.6 & 0.12 & 0.83 \\
Linear range, $\mathrm{ng} / \mathrm{mL}$ & $5.0-60$ & $0.25-2.0$ & $1.0-8.0$ \\
$R^{2}$ & 0.9991 & 0.9985 & 0.9981 \\
Equation & $y=0.0059 x+0.0028$ & $y=0.2414 x+0.0705$ & $y=0.0408 x+0.0176$ \\
\hline
\end{tabular}

TABLE 4: Accuracy of the method used.

\begin{tabular}{llcc}
\hline & CRM & Result certified (STD), ng/mL & Result found (STD), ng/mL \\
\hline $\mathrm{As}$ & Trace Element in Water, 1643e & $60.45(0.72)$ & $60.88(1.99)$ \\
$\mathrm{Cd}$ & Trace Element in Water, 1643e & $6.568(0.073)$ & $6.50(0.33)$ \\
$\mathrm{Pb}$ & Trace Element in Water, 1643e & $19.63(0.21)$ & $21.08(1.69)$ \\
\hline
\end{tabular}

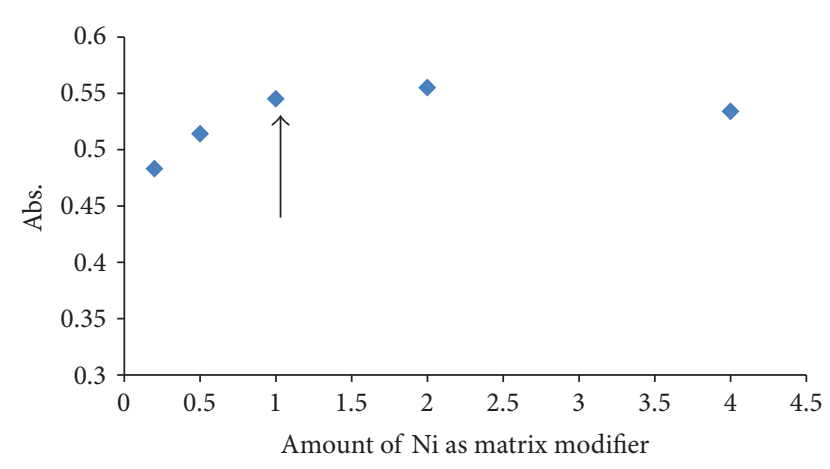

FIGURE 2: Optimization of the amount of matrix modifier $(\mu \mathrm{g})$ by using $2.0 \mathrm{ng} / \mathrm{mL}$ of cadmium.

it is capable of not only the prevention of analyte losses during graphite furnace cycle but also the improvement of sensitivity.

Selection of suitable matrix modifier for electrothermal atomization of lead was also performed. For this purpose, $\mathrm{Pd}, \mathrm{Ni}, \mathrm{Mg}$, and Pd-Mg mixture were tried. $10.0 \mathrm{ng} / \mathrm{mL}$ of lead standard and 1.0 microgram of each modifier were used throughout the optimization. The highest lead signal was obtained in the case of $\mathrm{Ni}$ as chemical modifier. No difference was observed in the lead signals obtained with and without $\mathrm{Pd}$ as matrix modifier. In the optimization of $\mathrm{Ni}$ amount, $0.2,0.5$, $1.0,2.0,4.0,5.0$, and $6.0 \mu \mathrm{g}$ were tested. The highest lead signal was obtained in the case of $5.0 \mu \mathrm{g}$ Ni used. Hence, $5.0 \mu \mathrm{g}$ of nickel was selected as the optimal matrix modifier for the further studies.

3.3. Analytical Figures of Merit. Analytical characteristics of the optimized GFAAS system including the linear range, limit of detection, limit of quantification, and best line equation are summarized in Table 3. In the calculation of limit of detection (LOD) and limit of quantification (LOQ), $3 \mathrm{~s} / \mathrm{m}$ where $\mathrm{s}$ is standard deviation of lowest concentration of linear range and $10 \mathrm{~s} / \mathrm{m}$ were used, respectively.

It is clear in Table 3 that detection limit for Cd using the nickel as matrix modifier and optimum temperature program is better than the values found for $\mathrm{As}$ and $\mathrm{Pb}$. Linear ranges for $\mathrm{As}, \mathrm{Cd}$, and $\mathrm{Pb}$ were in the range of 5.0-60, 0.25-2.0, and $1.0-8.0 \mathrm{ng} / \mathrm{mL}$, respectively. $R^{2}$ values for each analyte were found to be at least 0.998 .

3.4. Accuracy Check. Evaluation of accuracy was performed using standard reference material (Trace Element in Water, 1643e). Results are given in Table 4.

Concentrations of $\mathrm{As}, \mathrm{Cd}$, and $\mathrm{Pb}$ were found as 60.88 $\pm 1.99,6.50 \pm 0.33,21.08 \pm 1.69 \mathrm{ng} / \mathrm{mL}$, respectively. The certified values of the analytes were reported as $60.45 \pm 0.72$ for As, $6.568 \pm 0.073$ for $\mathrm{Cd}$, and $19.63 \pm 0.21 \mathrm{ng} / \mathrm{mL}$ for $\mathrm{Pb}$. According to Students $t$-test at $95 \%$ confidence level calculated and reported values are the same. It is clear that high level accuracy of the GFAAS method is demonstrated by the good agreement of the results found in the analysis of standard reference material with the values certified.

3.5. Analysis of Water Samples for Their As, Cd, and Pb Contents. Many elements are present in water samples playing important functions in the human body. Their levels remain within the specified ranges which are recommended by the World Health Organization [29]. Trace levels of metals which are normally not harmful to human health are common in water. Exposure to lead, cadmium, and arsenic is the main trouble to human health from heavy metals [30]. Guideline values for $\mathrm{As}, \mathrm{Cd}$, and $\mathrm{Pb}$ which are of health significance in drinking water is $10,3.0$, and $10 \mu \mathrm{g} / \mathrm{L}$, respectively [29]. For the region interested in this study, there have been no studies in the literature for the quantitative determination of As, $\mathrm{Cd}$, and $\mathrm{Pb}$ in drinking and bottled water samples; however, there are some literature where heavy metals have been determined in water samples taken from different regions of Turkey [31-33]. In this study, 78 tap water samples and 17 different brands of bottled water samples consumed in Kocaeli, Adapazarı, and Düzce cities located in the west part of Turkey were analyzed for their $\mathrm{As}, \mathrm{Cd}$, and $\mathrm{Pb}$ contents under the optimum conditions. Standard addition method was also applied to make sure whether there is any interferences coming from matrix or not. There is no difference observed in the slopes of both direct calibration and standard addition method. Hence, direct calibration 
TABLE 5: As, Cd, and $\mathrm{Pb}$ results of the samples analyzed.

\begin{tabular}{|c|c|c|c|}
\hline Sample Number & As, $\mathrm{ng} / \mathrm{mL}$ & $\mathrm{Cd}, \mathrm{ng} / \mathrm{mL}$ & $\mathrm{Pb}, \mathrm{ng} / \mathrm{mL}$ \\
\hline TW1 & N.D. & N.D. & $3.50 \pm 0.23$ \\
\hline TW2 & N.D. & N.D. & $3.15 \pm 0.21$ \\
\hline TW3 & N.D. & N.D. & N.D. \\
\hline TW4 & N.D. & N.D. & N.D. \\
\hline TW5 & N.D. & N.D. & $2.03 \pm 0.13$ \\
\hline TW6 & N.D. & N.D. & $3.42 \pm 0.22$ \\
\hline TW7 & N.D. & N.D. & $2.86 \pm 0.19$ \\
\hline TW8 & N.D. & N.D. & N.D. \\
\hline TW9 & N.D. & N.D. & N.D. \\
\hline TW10 & N.D. & N.D. & $3.15 \pm 0.21$ \\
\hline TW11 & N.D. & N.D. & $2.86 \pm 0.19$ \\
\hline TW12 & N.D. & N.D. & $2.33 \pm 0.15$ \\
\hline TW13 & N.D. & N.D. & $3.98 \pm 0.26$ \\
\hline TW14 & N.D. & N.D. & $2.59 \pm 0.17$ \\
\hline TW15 & N.D. & N.D. & $3.15 \pm 0.21$ \\
\hline TW16 & $9.14 \pm 0.75$ & N.D. & $2.33 \pm 0.15$ \\
\hline TW17 & $9.20 \pm 0.68$ & N.D. & $2.33 \pm 0.15$ \\
\hline TW18 & N.D. & N.D. & N.D. \\
\hline TW19 & N.D. & N.D. & $2.59 \pm 0.17$ \\
\hline TW20 & $8.51 \pm 1.20$ & N.D. & $2.33 \pm 0.15$ \\
\hline TW21 & $8.72 \pm 1.35$ & N.D. & $2.33 \pm 0.15$ \\
\hline TW22 & $9.04 \pm 1.80$ & N.D. & $2.33 \pm 0.15$ \\
\hline TW23 & N.D. & N.D. & $2.86 \pm 0.19$ \\
\hline TW24 & N.D. & N.D. & $2.10 \pm 0.11$ \\
\hline TW25 & N.D. & N.D. & $2.40 \pm 0.13$ \\
\hline TW26 & N.D. & N.D. & $2.59 \pm 0.14$ \\
\hline TW27 & N.D. & N.D. & $3.77 \pm 0.20$ \\
\hline TW28 & N.D. & N.D. & $1.61 \pm 0.09$ \\
\hline TW29 & N.D. & N.D. & $12.66 \pm 0.68$ \\
\hline TW30 & N.D. & N.D. & $2.59 \pm 0.14$ \\
\hline TW31 & N.D. & N.D. & $2.99 \pm 0.16$ \\
\hline TW32 & N.D. & N.D. & $2.20 \pm 0.12$ \\
\hline TW33 & N.D. & N.D. & $2.79 \pm 0.15$ \\
\hline TW34 & N.D. & N.D. & N.D. \\
\hline TW35 & N.D. & N.D. & N.D. \\
\hline TW36 & N.D. & N.D. & $1.42 \pm 0.08$ \\
\hline TW37 & N.D. & N.D. & $2.01 \pm 0.11$ \\
\hline TW38 & N.D. & N.D. & $2.59 \pm 0.14$ \\
\hline TW39 & N.D. & N.D. & $1.42 \pm 0.08$ \\
\hline TW40 & $10.06 \pm 0.82$ & N.D. & N.D. \\
\hline TW41 & $11.54 \pm 2.79$ & N.D. & $1.42 \pm 0.08$ \\
\hline TW42 & $9.13 \pm 0.99$ & N.D. & N.D. \\
\hline TW43 & $9.11 \pm 1.03$ & N.D. & $1.42 \pm 0.08$ \\
\hline TW44 & N.D. & N.D. & $2.40 \pm 0.13$ \\
\hline TW45 & N.D. & N.D. & $3.18 \pm 0.17$ \\
\hline TW46 & N.D. & N.D. & N.D. \\
\hline TW47 & N.D. & N.D. & N.D. \\
\hline TW48 & N.D. & N.D. & N.D. \\
\hline TW49 & N.D. & N.D. & N.D. \\
\hline TW50 & N.D. & N.D. & N.D. \\
\hline TW51 & N.D. & N.D. & $1.00 \pm 0.09$ \\
\hline
\end{tabular}

TABLE 5: Continued.

\begin{tabular}{|c|c|c|c|}
\hline Sample Number & As, ng/mL & $\mathrm{Cd}, \mathrm{ng} / \mathrm{mL}$ & $\mathrm{Pb}, \mathrm{ng} / \mathrm{mL}$ \\
\hline TW52 & N.D. & N.D. & $1.04 \pm 0.08$ \\
\hline TW53 & N.D. & N.D. & N.D. \\
\hline TW54 & N.D. & N.D. & N.D. \\
\hline TW55 & N.D. & N.D. & N.D. \\
\hline TW56 & N.D. & N.D. & N.D. \\
\hline TW57 & N.D. & N.D. & N.D. \\
\hline TW58 & N.D. & N.D. & N.D. \\
\hline TW59 & N.D. & N.D. & N.D. \\
\hline TW60 & N.D. & N.D. & N.D. \\
\hline TW61 & N.D. & N.D. & N.D. \\
\hline TW62 & N.D. & N.D. & $1.50 \pm 0.07$ \\
\hline TW63 & N.D. & N.D. & N.D. \\
\hline TW64 & N.D. & N.D. & N.D. \\
\hline TW65 & N.D. & N.D. & N.D. \\
\hline TW66 & N.D. & N.D. & N.D. \\
\hline TW67 & N.D. & N.D. & N.D. \\
\hline TW68 & N.D. & N.D. & N.D. \\
\hline TW69 & N.D. & N.D. & N.D. \\
\hline TW70 & N.D. & N.D. & N.D. \\
\hline TW71 & N.D. & N.D. & $1.51 \pm 0.06$ \\
\hline TW72 & N.D. & N.D. & N.D. \\
\hline TW73 & N.D. & N.D. & N.D. \\
\hline TW74 & N.D. & N.D. & N.D. \\
\hline TW75 & N.D. & N.D. & N.D. \\
\hline TW76 & N.D. & N.D. & N.D. \\
\hline TW77 & N.D. & N.D. & $2.40 \pm 0.15$ \\
\hline TW78 & N.D. & N.D. & N.D. \\
\hline BW1 & N.D. & N.D. & $2.99 \pm 0.16$ \\
\hline BW2 & N.D. & N.D. & $4.13 \pm 0.22$ \\
\hline BW3 & N.D. & N.D. & $1.78 \pm 0.10$ \\
\hline BW4 & N.D. & N.D. & $2.46 \pm 0.13$ \\
\hline BW5 & N.D. & N.D. & $2.79 \pm 0.15$ \\
\hline BW6 & N.D. & N.D. & $2.46 \pm 0.13$ \\
\hline BW7 & N.D. & N.D. & $2.10 \pm 0.11$ \\
\hline BW8 & N.D. & N.D. & N.D. \\
\hline BW9 & N.D. & N.D. & $2.46 \pm 0.13$ \\
\hline BW10 & N.D. & N.D. & N.D. \\
\hline BW11 & N.D. & N.D. & $4.82 \pm 0.26$ \\
\hline BW12 & N.D. & N.D. & $2.10 \pm 0.11$ \\
\hline BW13 & N.D. & N.D. & $1.78 \pm 0.10$ \\
\hline BW14 & N.D. & N.D. & $1.78 \pm 0.10$ \\
\hline BW15 & N.D. & N.D. & $2.79 \pm 0.15$ \\
\hline BW16 & N.D. & N.D. & $3.12 \pm 0.17$ \\
\hline BW17 & N.D. & N.D. & $2.10 \pm 0.11$ \\
\hline
\end{tabular}

method was applied throughout the analysis of all samples. Concentrations of analytes found in the samples of interest in this study are presented in Table 5.

It is clear that concentration of arsenic in bottled water samples was found to be below detection limits while nine water samples contained detectable levels of arsenic in the 
range of $8.51-11.54 \mu \mathrm{g} / \mathrm{L}$. Two tap water samples exceeded the safe limit of $10 \mathrm{mg} / \mathrm{L}$ given in WHO. It is clear that bottled water samples do not fall under toxic and alert categories with respect to arsenic.

Based on the safe limit set by WHO for cadmium at $3.0 \mu \mathrm{g} / \mathrm{L}$, none of the tap water and bottled water samples exceeded the specifications. Cd concentration for all samples was found to be lower than detection limit. This is good news for the people who live in this area because there are some indications that cadmium is carcinogenic by the inhalation route. In addition, according to IARC, cadmium and cadmium compounds accumulating primarily in the kidneys and having long biological half-life in humans of 10-35 years are classified in Group 2A [29].

Lead was found in 37 (47.4\%) tap water samples in which one of the samples $(12.66 \pm 0.68 \mu \mathrm{g} / \mathrm{L})$ does not obey the regulations on safe limit of lead in water by WHO. Detectable lead concentration in tap water samples was found to be in the range of $1.00 \pm 0.09-12.66 \pm 0.68 \mu \mathrm{g} / \mathrm{L}$. For bottled water samples, although detectable levels of lead were found in $88.2 \%$ of the samples interested $(1.78 \pm 0.10-4.82 \pm 0.26 \mu \mathrm{g} / \mathrm{L})$, none of the samples exceeded the WHO safe limit of $10 \mu \mathrm{g} / \mathrm{L}$.

\section{Conclusion}

Determination of trace amounts of arsenic, cadmium, and lead in tap water and bottled water samples consumed in Kocaeli, Adapazarı, and Düzce cities of Turkey was performed by graphite furnace atomic absorption spectrometry. All of the system parameters were optimized to obtain lower detection limits. Direct calibration method was applied throughout the sample analysis. Nickel was selected as effective matrix modifier for the determination of both cadmium and lead, while the highest arsenic signal was obtained in the case of palladium-magnesium mixture as matrix modifier. In order to verify the accuracy of the GFAAS method with the optimum matrix modifiers selected, certified reference of Trace Element in Water, 1643e was analyzed and the results obtained were in good agreement with the certified values for all analytes. In the real sample analysis, detectable levels of arsenic were found in the range of $8.51-11.54 \mu \mathrm{g} / \mathrm{L}$ in tap water samples while this element was not detected in bottled water samples. There is no analytical signal observed for cadmium for all the samples analyzed. Analysis of lead in 78 tap water and 17 bottled water samples showed that concentration of this element in all of the samples with the exception of TW29 with $12.66 \pm 0.68 \mu \mathrm{g} / \mathrm{L}$ was below safe limit of $10.0 \mu \mathrm{g} / \mathrm{L}$ accepted by WHO. From all the experiment results obtained, it could be concluded that there is no extensive nature of metal contamination ( $\mathrm{As}, \mathrm{Cd}$, and $\mathrm{Pb}$ ) of tap water and bottled water samples consumed in the area interested.

\section{References}

[1] K. Naeem, W. Yawar, P. Akhter, and I. Rehana, "Atomic absorption spectrometric determination of cadmium and lead in soil after total digestion," Asia-Pacific Journal of Chemical Engineering, vol. 7, pp. 295-301, 2012.
[2] S. Kapaj, H. Peterson, K. Liber, and P. Bhattacharya, "Human health effects from chronic arsenic poisoning-a review," Journal of Environmental Science and Health Part A, vol. 41, no. 10, pp. 2399-2428, 2006.

[3] C. Steinmaus, Y. Yuan, M. N. Bates, and A. H. Smith, "Casecontrol study of bladder cancer and drinking water arsenic in the western United States," American Journal of Epidemiology, vol. 158, no. 12, pp. 1193-1201, 2003.

[4] M. I. Luster and P. P. Simeonova, "Arsenic and urinary bladder cell proliferation," Toxicology and Applied Pharmacology, vol. 198, no. 3, pp. 419-423, 2004.

[5] H. F. Chiu, S. C. Ho, and C. Y. Yang, "Lung cancer mortality reduction after installation of tap-water supply system in an arseniasis-endemic area in Southwestern Taiwan," Lung Cancer, vol. 46, no. 3, pp. 265-270, 2004.

[6] S. Y. Tsai, H. Y. Chou, H. W. The, C. M. Chen, and C. J. Chen, "The effects of chronic arsenic exposure from drinking water on the neurobehavioral development in adolescence," NeuroToxicology, vol. 24, no. 4-5, pp. 747-753, 2003.

[7] M. B. Dessuy, M. G. R. Vale, B. Welz, A. R. Borges, M. M. Silva, and P. B. Martelli, "Determination of cadmium and lead in beverages after leaching from pewter cups using graphite furnace atomic absorption spectrometry," Talanta, vol. 85, no. 1, pp. 681-686, 2011.

[8] H. C. Rezende, C. C. Nascentes, and N. M. M. Coelho, "Cloud point extraction for determination of cadmium in soft drinks by thermospray flame furnace atomic absorption spectrometry," Microchemical Journal, vol. 97, no. 2, pp. 118-121, 2011.

[9] J. A. Mendez, J. B. Garcia, R. M. P. Crecente, S. G. Martin, and C. H. Latorre, "A new flow injection preconcentration method based on multiwalled carbon nanotubes for the ETA-AAS determination of Cd in urine," Talanta, vol. 85, pp. 2361-2367, 2011.

[10] V. Verougstraete, D. Lison, and P. Hotz, "Cadmium, lung and prostate cancer: a systematic review of recent epidemiological data," Journal of Toxicology and Environmental Health Part B, vol. 6, no. 3, pp. 227-255, 2003.

[11] S. J. S. Flora, P. Gautam, and P. Kushwaha, "Lead and ethanol co-exposure lead to blood oxidative stress and subsequent neuronal apoptosis in rats," Alcohol and Alcoholism, vol. 47, pp. 92-101, 2012.

[12] S. J. S. Flora, G. Saxena, and A. Mehta, "Reversal of leadinduced neuronal apoptosis by chelation treatment in rats: role of reactive oxygen species and intracellular $\mathrm{Ca}^{2+}$, Journal of Pharmacology and Experimental Therapeutics, vol. 322, no. 1, pp. 108-116, 2007.

[13] M. Ahamed and M. K. J. Siddiqui, "Environmental lead toxicity and nutritional factors," Clinical Nutrition, vol. 26, no. 4, pp. 400-408, 2007.

[14] J. O. Nriagu and J. M. Pacyna, "Quantitative assessment of worldwide contamination of air, water and soils by trace metals," Nature, vol. 333, no. 6169, pp. 134-139, 1988.

[15] S. Bakirdere and M. Yaman, "Determination of lead, cadmium and copper in roadside soil and plants in Elazig, Turkey," Environmental Monitoring and Assessment, vol. 136, no. 1-3, pp. 401-410, 2008.

[16] H. B. Ulusoy, M. Akay, and R. Gürkan, "Development of an inexpensive and sensitive method for the determination of low quantity of arsenic species in water samples by CPE-FAAS," Talanta, vol. 85, no. 3, pp. 1585-1591, 2011.

[17] J. Sardans, F. Montes, and J. Peñuelas, "Determination of As, Cd, $\mathrm{Cu}, \mathrm{Hg}$ and $\mathrm{Pb}$ in biological samples by modern electrothermal 
atomic absorption spectrometry," Spectrochimica Acta, vol. 65, no. 2, pp. 97-112, 2010.

[18] V. L. Atz and D. Pozebon, "Graphite furnace atomic absorption spectrometry (GFAAS) methodology for trace element determination in eye shadow and lipstick," Atomic Spectroscopy, vol. 30, no. 3, pp. 82-91, 2009.

[19] F. Chen, D. D. Xu, X. P. Tang, J. Cao, Y. T. Liu, and J. Deng, "Determination of nine hazardous elements in textiles by inductively coupled plasma optical emission spectrometer after microwave-assisted dilute nitric acid extraction," Spectroscopy and Spectral Analysis, vol. 32, pp. 239-243, 2012.

[20] M. Bingöl, G. Yentür, B. Er, and A. B. Öktem, "Determination of some heavy metal levels in soft drinks from Turkey using ICPOES method," Czech Journal of Food Sciences, vol. 28, no. 3, pp. 213-216, 2010.

[21] S. D’Ilio, C. Majorani, F. Petrucci, N. Violante, and O. Senofonte, "Method validation for the quantification of As, Cd, $\mathrm{Hg}$ and $\mathrm{Pb}$ in blood by ICP-MS for monitoring purposes," Analytical Methods, vol. 2, no. 12, pp. 2049-2054, 2010.

[22] M. G. Minnich, D. C. Miller, and P. J. Parsons, "Determination of $\mathrm{As}, \mathrm{Cd}, \mathrm{Pb}$, and $\mathrm{Hg}$ in urine using inductively coupled plasma mass spectrometry with the direct injection high efficiency nebulizer," Spectrochimica Acta, vol. 63, no. 3, pp. 389-395, 2008.

[23] M. Yaman, M. Güneş, and S. Bakirdere, "Contamination of aluminium from cooking utensils and yogurt containers," Bulletin of Environmental Contamination and Toxicology, vol. 70, no. 3, pp. 437-442, 2003.

[24] M. Yaman and S. Bakirdere, "Identification of chemical forms of lead, cadmium and nickel in sewage sludge of waste water treatment facilities," Mikrochimica Acta, vol. 141, no. 1-2, pp. 47-54, 2003.

[25] M. Yaman and I. Akdeniz, "Effects of different chemical modifiers on the determination of arsenic by electrothermal atomic absorption spectrometry and application to the poultry and plant samples," Trace Elements and Electrolytes, vol. 23, no. 4, pp. 237-241, 2006.

[26] J. É. Surlève-Bazeille, M. Mercier, R. Tarroux et al., "Development of a microwave sample preparation method for the determination of arsenic in humus and moss samples by graphite furnace atomic absorption spectrometry," Analusis, vol. 28 , no. 9 , pp. $830-834,2000$.

[27] S. Pai, F. Lin, C. Tseng, and D. Sheu, "Optimization of heating programs of gfaas for the determination of $\mathrm{Cd}, \mathrm{Cu}, \mathrm{Ni}$ and $\mathrm{pb}$ in sediments using sequential extraction technique," International Journal of Environmental Analytical Chemistry, vol. 50, pp. 193-205, 1993.

[28] C. Blake and B. Bourqui, "Determination of lead and cadmium in food products by graphite furnace atomic absorption spectroscopy," Atomic Spectroscopy, vol. 19, no. 6, pp. 207-213, 1998.

[29] WHO, Guidelines For Drinking Water Quality, World Health Organization, Geneva, Switzerland, 3rd edition, 2004.

[30] M. Buragohain, B. Bhuyan, and H. P. Sarma, "Seasonal variations of lead, arsenic, cadmium and aluminium contamination of groundwater in Dhemaji district, Assam, India," Environmental Monitoring and Assessment, vol. 170, no. 1-4, pp. 345-351, 2010.

[31] A. Karatepe, M. Soylak, and L. Elçi, "Solid-phase extraction of some heavy metal ions on a double-walled carbon nanotube disk and determination by flame atomic absorption spectrometry," Journal of AOAC International, vol. 94, pp. 1617-1624, 2011.
[32] C. Duran, H. B. Senturk, L. Elci, M. Soylak, and M. Tufekci, "Simultaneous preconcentration of $\mathrm{Co}(\mathrm{II}), \mathrm{Ni}(\mathrm{II}), \mathrm{Cu}(\mathrm{II})$, and Cd(II) from environmental samples on Amberlite XAD-2000 column and determination by FAAS," Journal of Hazardous Materials, vol. 162, no. 1, pp. 292-299, 2009.

[33] I. Timur, B. F. Senkal, N. M. Karaaslan, B. Tulin, E. Cengiz, and M. Yaman, "Determination and removing of lead and nickel in water samples by solid phase extraction using a novel remazol black B-sulfonamide polymeric resin," Current Analytical Chemistry, vol. 7, pp. 286-295, 2011. 

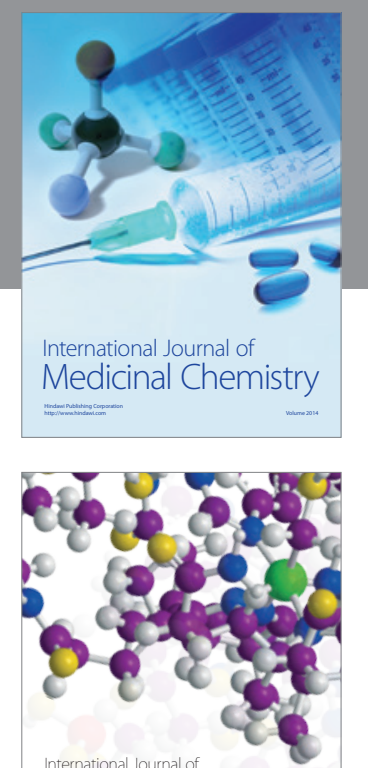

\section{Carbohydrate} Chemistry

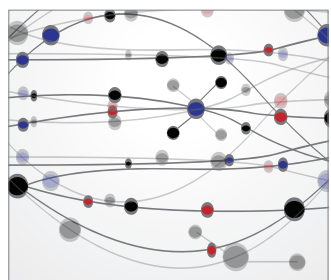

The Scientific World Journal
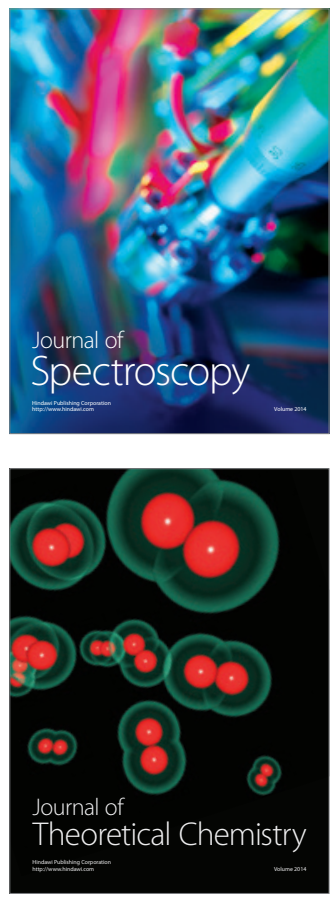
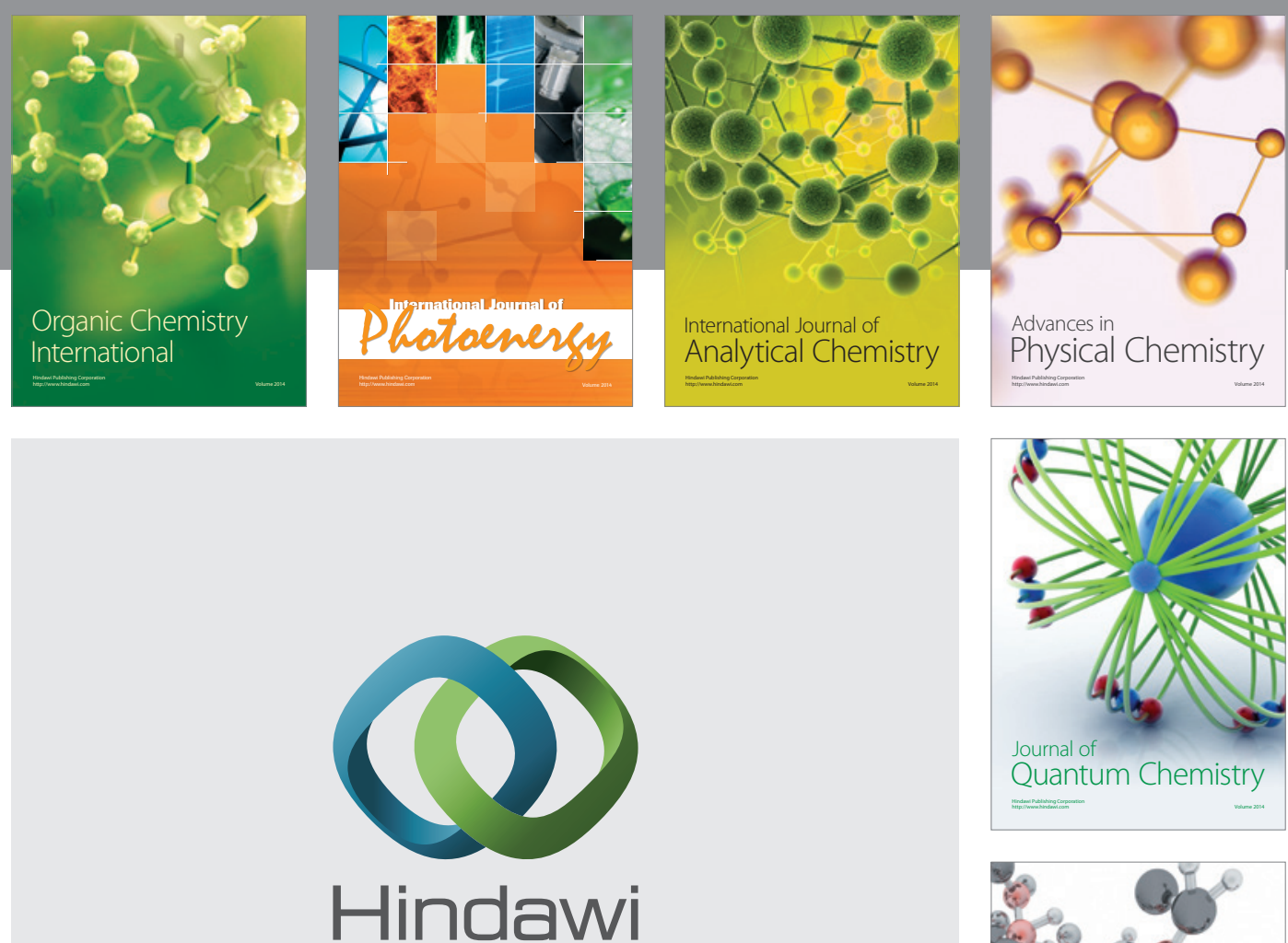

Submit your manuscripts at

http://www.hindawi.com

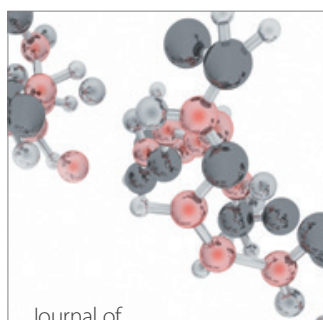

Analytical Methods

in Chemistry

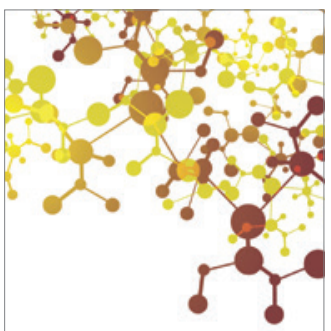

Journal of

Applied Chemistry

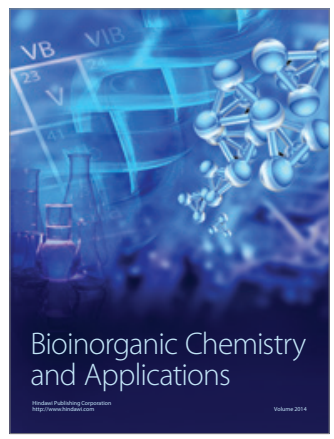

Inorganic Chemistry
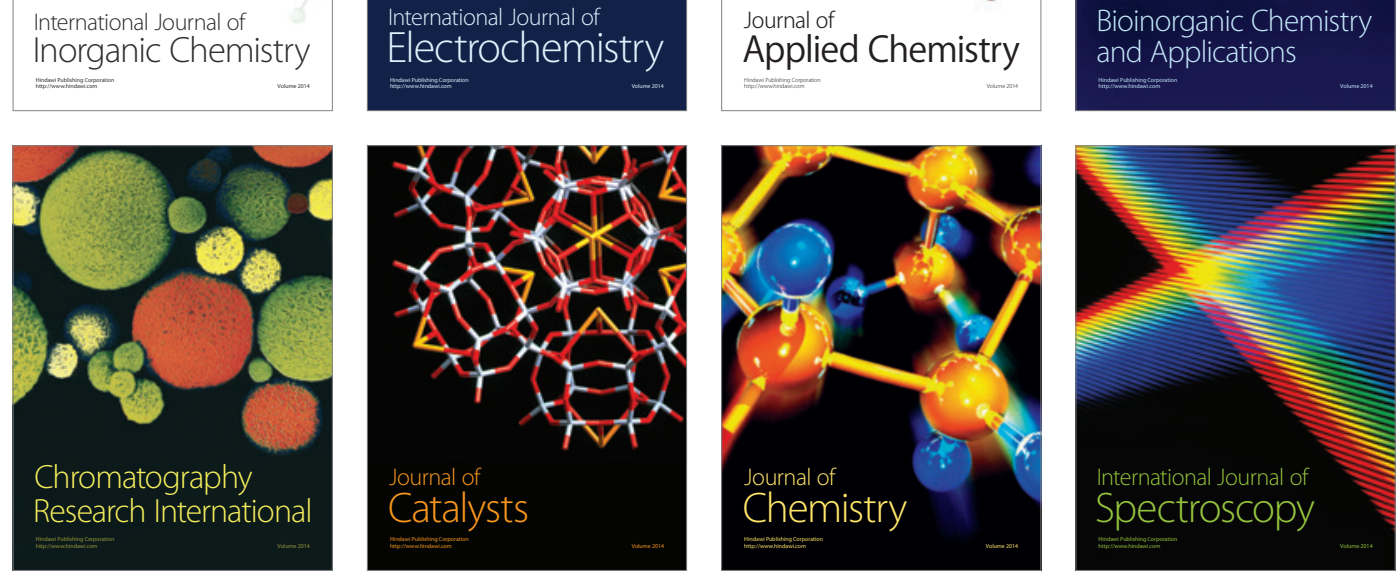